\title{
Tillering and biomass partitioning of Mombasa grass under nitrogen fertilization during regrowth
}

\author{
Américo Fróes Garcez Neto ${ }^{1,2}$, Kátia Fernanda Gobbi ${ }^{1,3}$, Janielen da Silva², Tiago Machado \\ dos Santos ${ }^{2}$
}

\author{
${ }^{1}$ Universidade Federal de Viçosa, Departamento de Zootecnia, Viçosa - MG, Brazil. \\ ${ }^{2}$ Universidade Federal do Paraná, Laboratório de Nutrição Animal, Palotina - PR, Brazil. \\ ${ }^{3}$ Instituto Agronômico do Paraná, Estação Experimental de Paranavaí, Paranavaí - PR, Brazil.
}

\begin{abstract}
Biomass partitioning in forages is highly variable during plant development and with the rate of nutrient supply. This study was carried out with the objective to evaluate the tillering pattern and biomass partitioning of Mombasa grass (Megathyrsus maximus cv. Mombaça) subjected to rates of nitrogen $(\mathrm{N})$ during regrowth. The treatments consisted of three weekly rates of $\mathrm{N}$ : control (without $\mathrm{N}$ supply), 25 and $50 \mathrm{mg} \mathrm{dm}^{-3}$ of $\mathrm{N}$, which were evaluated by 1, 2, 4, 8, 16 and 32 days after defoliation. The design was of completely randomized blocks in a $3 \times 6$ factorial arrangement with three replicates. The number of tillers was measured and harvesting and weighting of the following morphological components were performed: leaf (leaf blades), pseudostem, stem base and root. Interaction between $\mathrm{N}$ rates and regrowth times was found for all variables analyzed. The N supply increased the number and weight of tiller (up to 117.3 and $167.6 \%$, respectively), as well as the shoot dry matter yield of Mombasa grass. That effect was most significant particularly at 32 days of regrowth. Among the treatments receiving $\mathrm{N}$ supply, the highest $\mathrm{N}$ rate was more significant to leaf and shoot yield only after 6-11 days of regrowth. High $\mathrm{N}$ supply must be applied to Mombasa grass only after that time and the biomass harvested between 24-28 days of regrowth.
\end{abstract}

Key Words: forage, morphology, structure, tiller

\section{Introduction}

Most of the milk, meat and wool produced in Brazil come from cattle raised on pastures. Therefore, it is expected that the improvement in the livestock yield in this region be increased with the use of high-yielding forages (Elyas et al., 2006; Alencar et al., 2010). Tropical grasses, such as Mombasa grass (Megathyrsus maximus cv. Mombasa), have shown high potential for dry matter yield supporting higher stocking rates and animal performance (Jank, 1995). However, their high yields depend on adequate soil fertility, so they can grow faster after successive and frequent defoliations (Gomide, 1993). Knowledge of the nutritional factors that influence the growth and development of forages is of fundamental importance to the establishment, management and persistence of forages (Belarmino et al., 2003).

High forage yield can be achieved by increasing the tissue flow that is provided by the use of fertilizers, especially nitrogen (Duru \& Ducrocq, 2000). Thus, N has been one of the most required nutrients and one of the most significant in the dry matter yield in established pastures (Whitehead, 1995).
Studies have shown strong influence of $\mathrm{N}$ in the morphological characteristics of forages. Lavres Júnior \& Monteiro (2003) observed an increase in tiller number, leaf area, and the length of roots of Mombasa grass with $\mathrm{N}$ supply. Also, significant effects were observed in the number of tillers, number of leaves per tiller, the rate of appearance and elongation of leaves, the leaf lifespan and the final length of the leaves due to $\mathrm{N}$ supply (Garcez Neto et al., 2002).

The persistence of established pastures depends on the continuous replacement of new tillers, which may be accelerated after defoliation of the plant. Nitrogen deficiency increases the number of dormant buds and affects tillering, so there is a dependency of the plant by an adequate intake of this nutrient since $\mathrm{N}$ has a major influence on plant morphogenesis (Nabinger \& Medeiros, 1995).

Due to the advantages obtained with the use of $\mathrm{N}$, the knowledge of appropriate $\mathrm{N}$ rates to provide improved performance of forages and increased animal production with best efficiency is very important. Thus, this study was carried out to evaluate the pattern of tillering, dry matter yield and biomass partitioning of Mombasa grass subjected 
to different rates of $\mathrm{N}$ during regrowth in order to determine the best time to use high $\mathrm{N}$ supply with this species.

\section{Material and Methods}

The experiment was carried out in a greenhouse of the Plant Growth Unit, at Universidade Federal de Viçosa, in Minas Gerais, Brazil. The local climate, according to the Köppen classification, is CWA subtropical with well defined rainy and dry seasons. The experimental site is located at an altitude of $651 \mathrm{~m}$ above sea level in the following coordinates: $20^{\circ} 45^{\prime} 40^{\prime \prime}$ south latitude and $42^{\circ} 51^{\prime} 40^{\prime \prime}$ west longitude.

The soil used in the experiment was classified as Oxisol of clay loam. Seeds of Megathyrsus maximus cv. Mombasa (syn. Panicum maximum) were sown in plastic trays containing sand as substrate. The trays were kept in a greenhouse with daily irrigation until transplanting to experimental pots. At 10 days of growth, plants were transplanted to plastic pots with $11 \mathrm{dm}^{3}$ of substrate. In each pot, four seedlings were transplanted. The substrate used in the pots consisted of mixture of soil and sand (3:1) in order to facilitate the management during root sampling. The substrate, before the transplant of seedlings, was limed for proper $\mathrm{pH}$ correction [Calcitic lime applied to base saturation $(\mathrm{V})=80 \%]$. During the growth of seedlings, all pots received a standard fertilization with $350 \mathrm{mg} \mathrm{dm}^{-3}$ of phosphorus (simple superphosphate, $20 \%$ of $\mathrm{P}_{2} \mathrm{O}_{5}$ ), $90 \mathrm{mg}$ $\mathrm{dm}^{-3}$ of potassium (potassium chloride, $58 \%$ of $\mathrm{K}_{2} \mathrm{O}$ ) and $25 \mathrm{mg} \mathrm{dm}^{-3}$ of nitrogen (ammonium sulphate, 18\% of $\mathrm{N}$ ). After completion of plant establishment (35 days), plants were subjected to a standardization cut to $10 \mathrm{~cm}$ height. After that cut, the plants received nitrogen fertilization for 35 days corresponding to rates of nitrogen $(0,25$ and $50 \mathrm{mg} \mathrm{dm}^{-3}$ per week) and a sole application of $90 \mathrm{mg} \mathrm{dm}^{-3}$ of potassium. That period was used as adaptation to nitrogen rates before the harvest periods.

The treatments consisted of three weekly rates of N: control (no fertilizer), 25 and $50 \mathrm{mg} / \mathrm{dm}^{3}$ and six harvest times, forming a $3 \times 6$ factorial arrangement in randomized block design with three replicates. The harvested period started after standardization cut (zero time) to 1, 2, 4, 8, 16 and 32 days during regrowth. At each sampling time, plants were cut to $5 \mathrm{~cm}$ above the ground. Nitrogen rates were applied weekly, with the first application starting at the day of the standardization cut. The $\mathrm{N}$ fertilizer used in treatments was ammonium sulphate diluted with water and applied on the substrate.
During the harvest period, the total number of tillers per pot was counted and morphological separations were carried out to weigh each of the following structures: leaf, pseudostem, stem base and root. Leaf:stem ratio, leaf mass ratio and root mass ratio were determined from biomass measurements. For the determination of dry matter fractions of each morphological component, samples were taken to a forced-ventilation oven at $80{ }^{\circ} \mathrm{C}$ for $24 \mathrm{~h}$. The roots were separated from the substrate by washing them over a $5.0 \mathrm{~mm}$ sieve, and then taken to the oven after removing the excess of water. The stem base fraction corresponded to segments of $5.0 \mathrm{~cm}$ height, with the remaining fraction of the stems classified as pseudostems.

Statistical analysis was performed using the GLM procedure of statistical package SAS (Statistical Analysis System, version 8.02). The effect of time and fertilization were analyzed from the interaction between harvest times and rates of $\mathrm{N}$. The characterization of both factors was performed through regression procedures from surface response studies. In all procedures of analysis, 5\% was adopted as significance level.

\section{Results and Discussion}

Interaction $(\mathrm{P}<0.05)$ between $\mathrm{N}$ supply and regrowth times was found for all variables evaluated (Table 1 and 2).

There was no significant effect of number of tillers on the treatment which was not supplied with N. For the treatment which received $25 \mathrm{mg} \mathrm{dm}^{-3}$ of $\mathrm{N}$, fewer tillers were found, compared with the treatment with $50 \mathrm{mg} \mathrm{dm}^{-3}$ of $\mathrm{N}$ during all regrowth period. Although the number of tillers between treatments with 25 and $50 \mathrm{mg} \mathrm{dm}^{-3}$ of $\mathrm{N}$ presented significant difference at 32 days, the rate of tiller yield was approximately two times higher for the treatment with $50 \mathrm{mg} \mathrm{N} / \mathrm{dm}^{3}$ over the whole period of regrowth (Figure 1).

Nitrogen fertilization significantly affects the appearance of tillers and interferes in the dynamics of tiller population of the pasture (Caminha et al., 2010). Nitrogen triggers the activation of dormant buds and enhances the site filling through the highest rate of tiller replacement, which supports a higher proportion of very active young tillers in the plant community, leading to greater productivity (Garcez Neto et al., 2002; Martuscello et al., 2005).

Lavres Júnior \& Monteiro (2003) also observed the effect of time on the number of tillers after cutting Mombasa grass fertilized with N. In the same study, authors found that in the second period of plant growth, the number of tillers was higher than that found in the first ones. According to 
the authors, this probably occurred because in its initial growth, the plant requires more energy for the formation of main roots and shoots, whereas after the establishment, the plant has enough root volume to supply more nutrients to be distributed between new tillers. In addition, the cutting process can also promote the induction of basal buds stimulating further tillering.
Batista \& Monteiro (2006), evaluating combinations of $\mathrm{N}$ and $\mathrm{S}$ rates on dry matter and morphological responses of Urochloa brizantha cv. Marandu, found that in the second cut, the amount of nitrogen needed for maximum production of shoots was $463,75 \mathrm{mg} \mathrm{dm}^{-3}$ of $\mathrm{N}$. According to the authors, the lowest yield of shoots for the first cut can be attributed to increased energy dependence on plant

Table 1 - Average of different morphological components of Mombasa grass subjected to nitrogen fertilization during regrowth

\begin{tabular}{|c|c|c|c|c|c|c|}
\hline \multirow{2}{*}{$\mathrm{N}\left(\mathrm{mg} / \mathrm{dm}^{3} /\right.$ week $)$} & \multicolumn{6}{|c|}{ Regrowth (days) } \\
\hline & 1 & 2 & 4 & 8 & 16 & 32 \\
\hline & \multicolumn{6}{|c|}{ Number of tillers/pot } \\
\hline 0 & $55.7(2.6)$ & $55.3(2.4)$ & $56.0(1.0)$ & $57.3(3.8)$ & $49.7(2.7)$ & $52.0(6.6)$ \\
\hline 25 & $70.3(3.5)$ & $69.7(5.4)$ & $60.7(5.2)$ & $67.3(4.9)$ & $80.3(5.2)$ & $89.7(2.6)$ \\
\hline \multirow[t]{2}{*}{50} & $69.7(1.8)$ & $68.3(4.5)$ & $72.7(6.2)$ & $73.7(3.9)$ & $108.0(9.2)$ & $113.0(6.8)$ \\
\hline & \multicolumn{6}{|c|}{ Tiller weight (g DM/tiller) } \\
\hline 0 & $0.198(0.014)$ & $0.269(0.028)$ & $0.276(0.009)$ & $0.295(0.025)$ & $0.512(0.021)$ & $0.752(0.025)$ \\
\hline 25 & $0.355(0.013)$ & $0.295(0.011)$ & $0.370(0.011)$ & $0.499(0.047)$ & $0.867(0.048)$ & $1.704(0.066)$ \\
\hline \multirow[t]{2}{*}{50} & $0.315(0.011)$ & $0.293(0.015)$ & $0.334(0.026)$ & $0.527(0.025)$ & $0.760(0.109)$ & $2.015(0.103)$ \\
\hline & \multicolumn{6}{|c|}{ Shoot (g DM/pot) } \\
\hline 0 & $11.0(0.9)$ & $14.8(1.0)$ & $15.4(0.4)$ & $16.7(0.9)$ & $25.3(0.4)$ & $38.8(3.8)$ \\
\hline 25 & $25.0(2.2)$ & $20.4(1.0)$ & $22.4(1.5)$ & $33.3(2.1)$ & $69.3(3.8)$ & $152.7(5.6)$ \\
\hline \multirow[t]{2}{*}{50} & $21.9(0.9)$ & $20.1(2.4)$ & $24.2(2.4)$ & $38.6(0.8)$ & $80.3(7.3)$ & $226.7(10.3)$ \\
\hline & \multicolumn{6}{|c|}{ Leaf (g DM/pot) } \\
\hline 0 & $0.2(0.0)$ & $0.6(0.1)$ & $2.3(0.1)$ & $4.2(0.6)$ & $9.6(0.0)$ & $19.2(2.1)$ \\
\hline 25 & $0.6(0.1)$ & $1.4(0.1)$ & $4.9(0.5)$ & $11.0(0.9)$ & $32.9(1.1)$ & $81.8(3.0)$ \\
\hline \multirow[t]{2}{*}{50} & $0.7(0.1)$ & $1.9(0.3)$ & $5.8(0.7)$ & $14.1(0.3)$ & $36.6(2.9)$ & $120.5(5.6)$ \\
\hline & \multicolumn{6}{|c|}{ Stem base (g DM/pot) } \\
\hline 0 & $7.3(0.8)$ & $8.0(0.6)$ & $8.0(0.0)$ & $7.8(0.0)$ & $9.1(0.2)$ & $11.4(1.1)$ \\
\hline 25 & $14.1(1.8)$ & $10.7(0.6)$ & $10.5(0.8)$ & $12.4(0.6)$ & $20.0(1.5)$ & $32.3(0.7)$ \\
\hline \multirow[t]{2}{*}{50} & $12.4(0.8)$ & $10.8(1.5)$ & $11.0(1.2)$ & $13.3(0.8)$ & $21.9(2.2)$ & $43.0(1.5)$ \\
\hline & \multicolumn{6}{|c|}{ Root (g DM/pot) } \\
\hline 0 & $26.2(3.3)$ & $25.4(1.5)$ & $23.1(2.5)$ & $18.9(1.1)$ & $24.5(0.3)$ & $32.1(3.5)$ \\
\hline 25 & $33.6(3.5)$ & $27.3(1.3)$ & $22.1(2.2)$ & $21.4(3.0)$ & $41.4(1.0)$ & $72.0(2.7)$ \\
\hline 50 & $30.6(1.1)$ & $22.3(0.3)$ & $23.9(2.9)$ & $25.3(2.7)$ & $33.6(5.0)$ & $97.3(17.3)$ \\
\hline
\end{tabular}

Values between parentheses represent the standard error of the mean.

Table 2 - Average of ratios between leaf, stem and root of Mombasa grass subjected to nitrogen fertilization during regrowth

\begin{tabular}{|c|c|c|c|c|c|c|}
\hline \multirow{2}{*}{$\mathrm{N}\left(\mathrm{mg} / \mathrm{dm}^{3} /\right.$ week $)$} & \multicolumn{6}{|c|}{ Regrowth (days) } \\
\hline & 1 & 2 & 4 & 8 & 16 & 32 \\
\hline & \multicolumn{6}{|c|}{ Leaf:stem ratio (g DM/g DM) } \\
\hline 25 & $0.023(0.003)$ & $0.075(0.007)$ & $0.279(0.024)$ & $0.493(0.012)$ & $0.907(0.045)$ & $1.156(0.018)$ \\
\hline \multirow[t]{2}{*}{50} & $0.033(0.005)$ & $0.106(0.004)$ & $0.315(0.025)$ & $0.579(0.014)$ & $0.840(0.020)$ & $1.136(0.020)$ \\
\hline & \multicolumn{6}{|c|}{ Root mass ratio (g DM/g DM) } \\
\hline \multirow[t]{2}{*}{50} & $0.583(0.002)$ & $0.529(0.026)$ & $0.496(0.023)$ & $0.394(0.026)$ & $0.292(0.016)$ & $0.296(0.028)$ \\
\hline & \multicolumn{6}{|c|}{ Leaf mass ratio (g DM/g DM) } \\
\hline 0 & $0.004(0.001)$ & $0.014(0.002)$ & $0.060(0.004)$ & $0.117(0.011)$ & $0.194(0.002)$ & $0.270(0.021)$ \\
\hline 25 & $0.010(0.001)$ & $0.030(0.003)$ & $0.110(0.006)$ & $0.202(0.005)$ & $0.297(0.002)$ & $0.364(0.007)$ \\
\hline 50 & $0.014(0.002)$ & $0.045(0.004)$ & $0.121(0.013)$ & $0.222(0.013)$ & $0.323(0.011)$ & $0.374(0.014)$ \\
\hline
\end{tabular}

Values between parentheses represent the standard error of the mean. 
establishment. After the formation of the root system, most of the energy can be used for the development of the shoot, contributing to higher harvestable biomass. Similar result was found by Mello et al. (2008), working with Mombasa grass, who observed a higher dry matter yield for the highest $\mathrm{N}$ rates. It is usually expected that there be proportionality between root and shoot structures. The natural balance between these structures enables extensive root systems to explore water and other nutrients in deeper layers of the soil, benefiting shoot growth under fertilization.

In a study with Mombasa grass, Mello et al. (2008) found higher tillering and dry matter yield between rates of 300 and $500 \mathrm{~kg} \mathrm{ha}^{-1}$ of $\mathrm{N}$. The higher demand of the authors for $\mathrm{N}$ probably resulted in higher responses both in plant height, size of leaves and stems, as well as tillering. Moreira et al. (2009), in a study with Urochloa decumbens, found a positive linear effect of $\mathrm{N}$ rates on the number of live tillers in the two years of study, and the regression equations estimated populations of 1496 and 2199 tillers $\mathrm{m}^{-2}$ for the first year and 1,545 and 3,145 tillers $\mathrm{m}^{-2}$ for the second year for rates of 75 and $300 \mathrm{~kg} \mathrm{ha}^{-1}$ of $\mathrm{N}$, respectively.

An increase of weight of tillers over time was observed for all treatments, but this increase was not constant between treatments. For the treatment without $\mathrm{N}$, the increase was at a rate lower than in other treatments (Figure 1). Santos et al. (2007), in a study with Aruana grass, observed positive correlation of tiller weight gains per generation of tillers with increasing $\mathrm{N}$ rates until the rate of $237.5 \mathrm{mg} \mathrm{dm}^{-3}$ of $\mathrm{N}$. Braga et al. (2004), using three levels of $\mathrm{N}$, observed a linear effect of the mean weight of the tiller of Mombasa grass as a function of $\mathrm{N}$ applied for both cutting intervals of 28 and 42 days. According to Martha Júnior et al. (2004), the increased availability of $\mathrm{N}$ in the soil affects the photosynthetic activity, mobilization of nutrient reserves and the leaf area expansion, thus a greater amount of available $\mathrm{N}$ results in greater accumulation of biomass per tiller.

Santos et al. (2009), performing the characterization of tillers on pastures of Signal grass deferred and fertilized with $\mathrm{N}$, found that both the deferment period and the $\mathrm{N}$ fertilization influenced the weight of all categories of tillers linearly. According to the authors, pastures deferred for a longer period remained more time with leaf area index (LAI) above the critical level. The increased stem elongation in that condition coupled with greater accumulation of leaves per tiller resulted in higher weight of vegetative, reproductive and dead tillers.

Although the weight of tillers and shoot yield of this study was almost the same between treatments with 25 and $50 \mathrm{mg} \mathrm{dm}^{-3}$ of $\mathrm{N}$ from four to eight days of regrowth, the

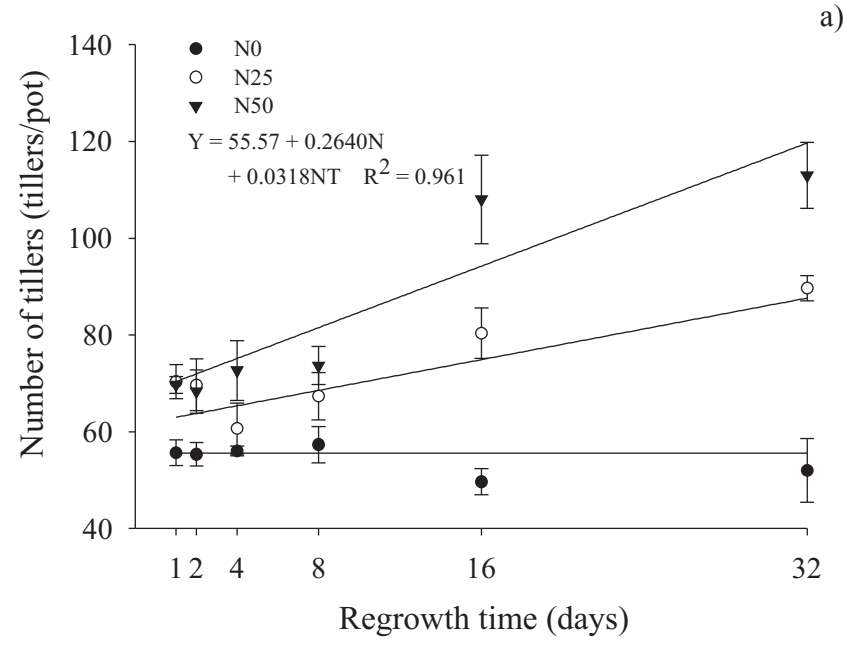

a)

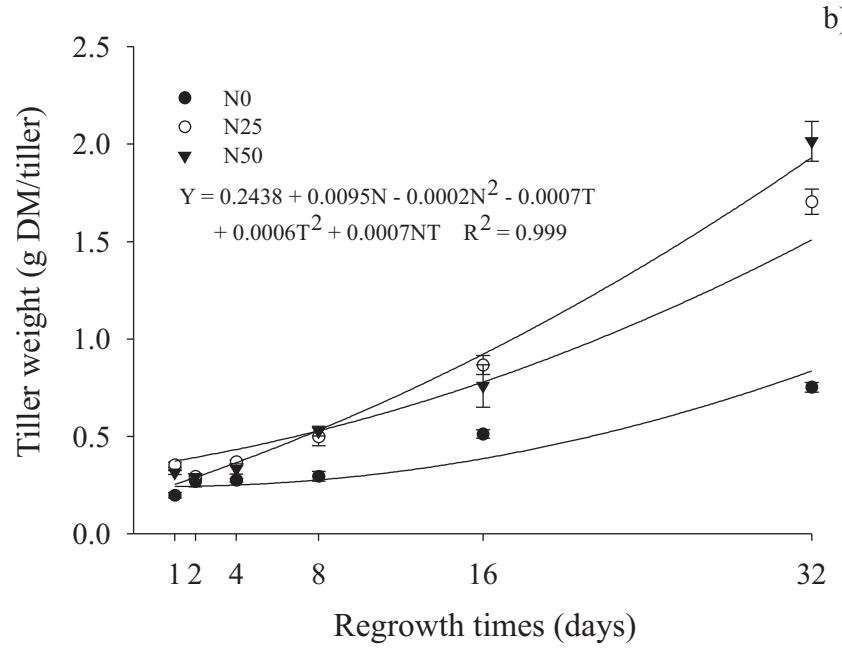

b)

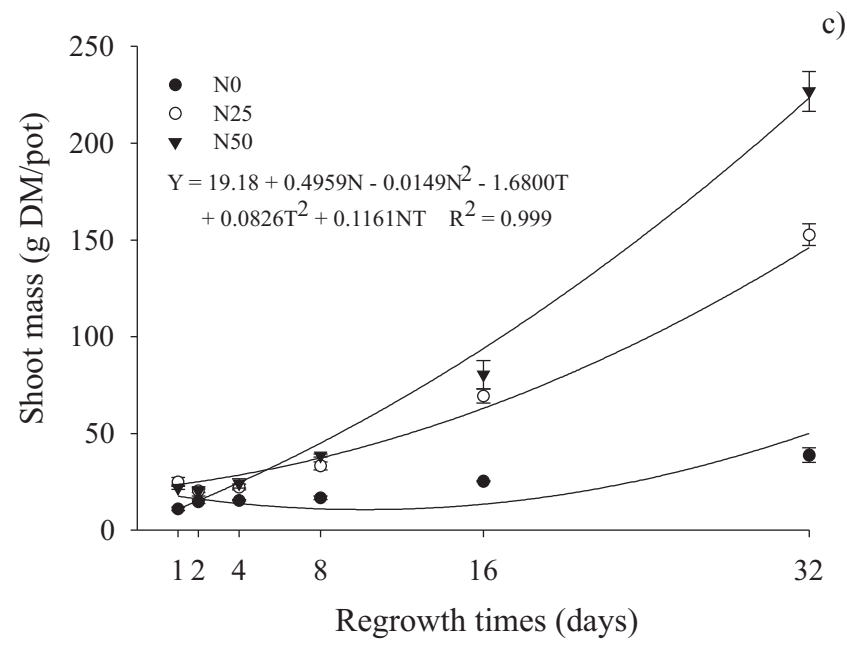

$\mathrm{N}$ - nitrogen supply; $\mathrm{T}$ - regrowth time.

Figure 1 - Number of tillers (a), tiller weight (b), and shoot mass (c) of Mombasa grass subjected to increasing concentration of $\mathrm{N}$ suppy $\left(0,25\right.$ and $50 \mathrm{mg} \mathrm{dm}^{-3}$ per week) during regrowth.

R. Bras. Zootec., v.41, n.8, p.1824-1831, 2012 
pattern of the regression curve reveals an important trend. After approximately eight days of regrowth, the tiller weight of the treatment with $50 \mathrm{mg} \mathrm{dm}^{-3}$ of $\mathrm{N}$ surpasses the curve of the treatment with $25 \mathrm{mg} \mathrm{dm}^{-3} \mathrm{~N}$ (Figure 1).

As found to weight of tillers the shoot mass becomes greater for treatment with $50 \mathrm{mg} \mathrm{N} / \mathrm{dm}^{3}$ approximately at eight days of regrowth (Figure 1). This yield is probably the result of the greater increase in tiller weight than in number of tillers. In new established pastures where individual plants do not need to deal with intense competition for resources, it is expected that the individuals contribute more to total forage mass. According to Hodgson (1990), plants at the beginning of their development after cutting usually show a simultaneous increase in the number and weight of tillers, as evidenced in this paper. In other studies, the increased supply of $\mathrm{N}$ stimulated both the appearance and the weight of tillers (Alwns in legume and stem base, rhizome and stolons in grasses. Defoliation usually causes a reduction in the concentration of carbohydrate reserves, but this reduction depends on the intensity and frequency of defoliation. The concentration of these organic reserves depends on whole plant energy balance. When availability of resources exceeds the amount used in growth and respiration, there is an accumulation of these reserves (Rodrigues et al., 2007).

The similar weight to the stem base especially between one and four days and for treatments with 25 and $50 \mathrm{mg}$ $\mathrm{dm}^{-3}$ of $\mathrm{N}$ may reflect a lower consumption of this plant reserves to resume leaf growth. In the treatment with higher $\mathrm{N}$ supply, no reduction in root weight was observed from standardization up to the final cut (Figure 2). That response may be due to less intense mobilization of nutrients by the plant for rapid yield of leaves. For plants with higher nitrogen supply, it is likely that the use of reserves is restricted to those found in the stem base instead of the root system. According to Lemaire \& Chapman (1996), approximately $80 \%$ of the $\mathrm{N}$ present in the shoot is formed in the first week after cutting or grazing, and that $\mathrm{N}$ can be derived from translocation from roots and stems with the remainder coming from the soil uptake. In this study, the larger mobilization of reserves from $\mathrm{N}$-deficient plants was probably caused by the root system when compared with the stem base, an argument supported by the variation of weight found in both organs during regrowth.

In fact, the treatment without $\mathrm{N}$ supply lost root weight until approximately thirteen days (Figure 2), probably reflecting a greater dependence of this treatment on the mobilization of nutrients to produce new leaves. Nitrogen deficient forages use most reserves from roots while well

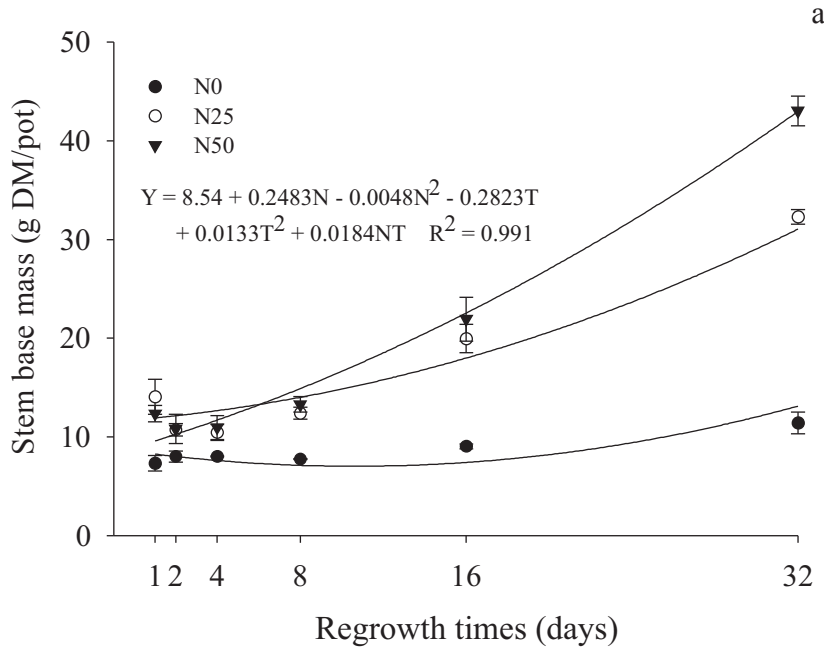

a)

b)
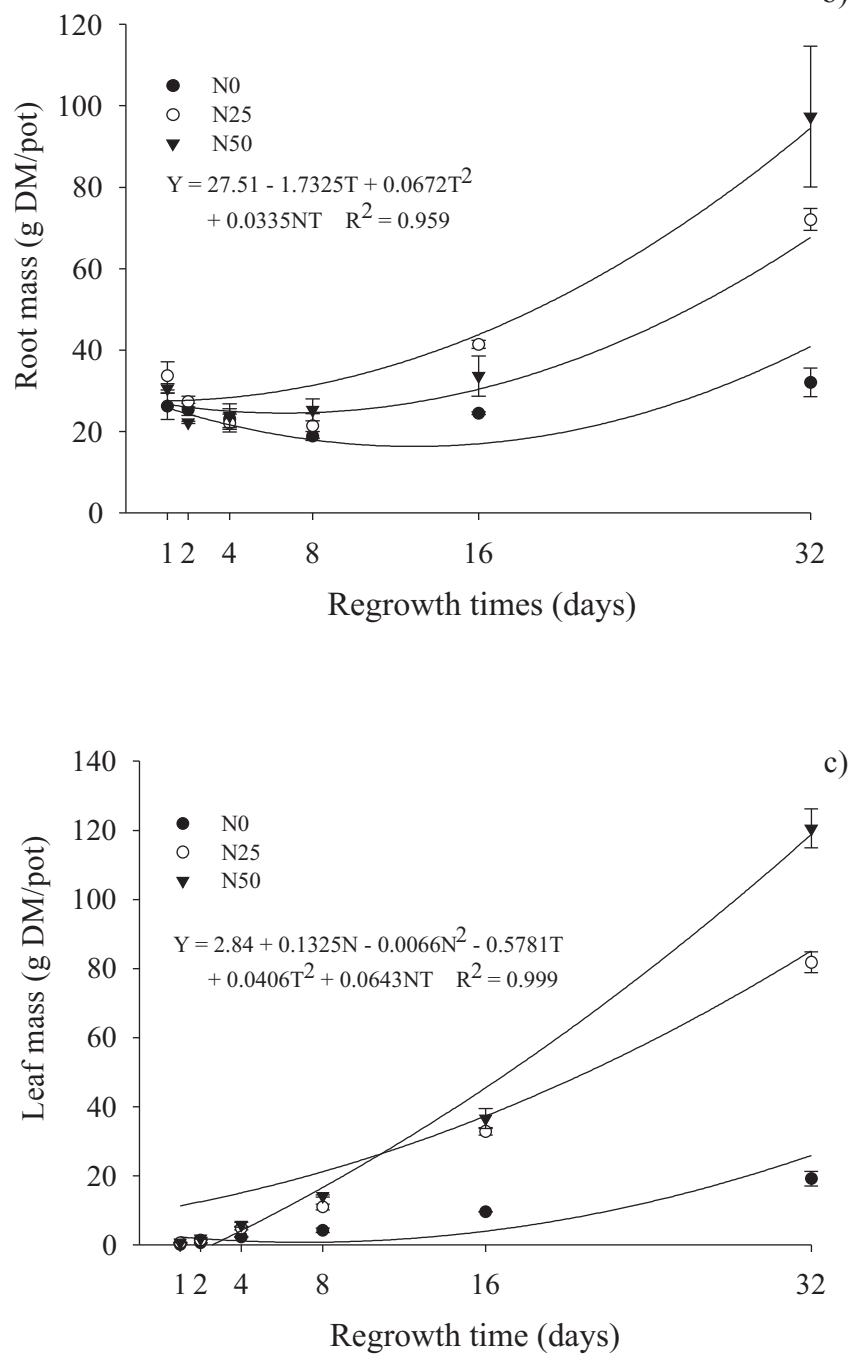

$\mathrm{N}$ - nitrogen supply; $\mathrm{T}$ - regrowth time.

Figure 2 - Steam base mass (a), root mass (b), and leaf mass (c) of Mombasa grass subjected to increasing concentration of $\mathrm{N}$ supply $\left(0,25\right.$ and $50 \mathrm{mg} \mathrm{dm}^{-3}$ per week) during regrowth. 
$\mathrm{N}$ supply forages use their reserves mainly from the stem

bases. Besides the changes between the allocation patterns of these reserves, the strengh of the mobilization has been less intense for well $\mathrm{N}$ supply plants. Batista \& Monteiro (2006), working with Palisade grass, found that at the lowest rate of $\mathrm{N}\left(14 \mathrm{mg}\right.$ of $\left.\mathrm{dm}^{-3} \mathrm{~N}\right)$, the root yield was, approximately, $6 \%$ of the maximum estimated. According to the authors, that response demonstrates the necessity of this plant to be supplied with $\mathrm{N}$ to support good root development. The small size and poor distribution of the root system reduce the ground support to sustain plant growth and constrain the overall nutrient uptake. However, the supply of nutrients like $\mathrm{N}$ positively influences the growth and morphology of the roots (Marschner, 1995).

An important response to characterize the pasture regrowth shows that the application of $\mathrm{N}$ was more significant in the production of leaves after approximately 11 days of regrowth (Figure 2). The positive effect of $\mathrm{N}$ fertilization on the leaf appearance rate (LAR) is widely reported in the literature under various conditions. Braga et al. (2000) found significant increase in leaf yield at higher rates of $\mathrm{N}$ (up to $200 \mathrm{~kg}$ ha- 1 of $\mathrm{N}$ ), particularly with 28 days of growth. Alexandrino et al. (2004), working with Urochloa brizantha cv. Marandu subjected to three rates of $\mathrm{N}$ fertilization $\left(0,20\right.$ and $40 \mathrm{mg} \mathrm{dm}^{-3}$ per week) and eight harvest times $(0,2,4,8,16,24,32$ and 48 days), found a positive linear effect of $\mathrm{N}$ on the LAR. According to Lemaire \& Chapman (1996), LAR plays a main role in the plant morphogenesis as it has a direct influence on each component of the sward structure (leaf size, number of leaves per tiller and tiller population). The combination of a number of factors also influences LAR, such as sheath height, leaf elongation and temperature (Duru \& Ducrocq, 2000).

The treatment without nitrogen supply had lower leaf production throughout the study period when compared with other treatments. Martuscello et al. (2005) also reported lower leaf production for the treatment without nitrogen compared with the treatment with $120 \mathrm{mg} \mathrm{N} / \mathrm{dm}^{3}$. Santos (2007), in a study with two cultivars of Urochloa (U. brizantha cv. Marandu and U. decumbens cv. Basilisk), showed that treatments containing $\mathrm{N}$ for both cultivars had higher number of leaves per day when compared with treatments without fertilizer. According to Whitehead (1995), deficiency of $\mathrm{N}$ limits the growth and development of individual leaves and their photosynthetic capacity, making the shoot growth more limited than the roots.

When the partitioning between different morphological components is presented through their biomass ratios (Figure 3), the significant effect of $\mathrm{N}$ fertilization driving the biomass to aerial components becomes evident. Without

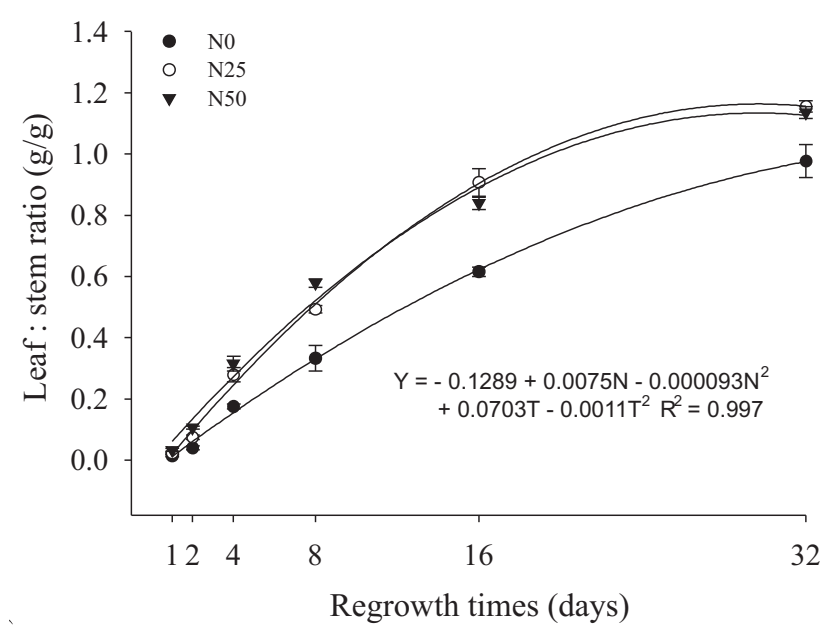

b)

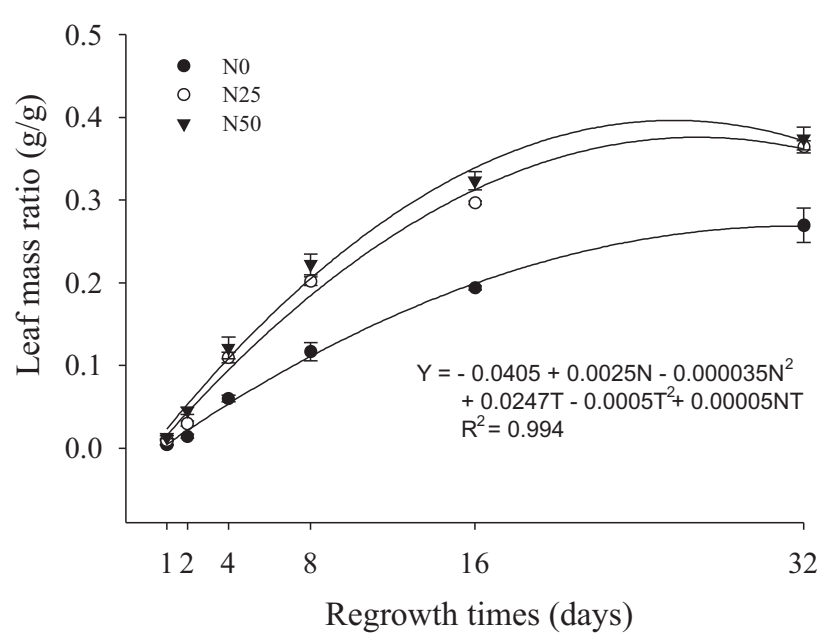

c)

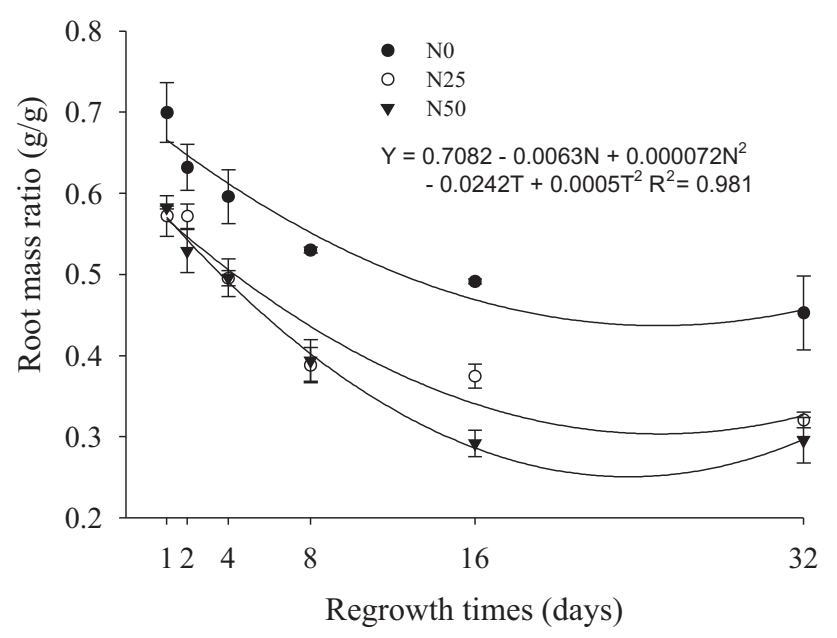

$\mathrm{N}$ - nitrogen supply; $\mathrm{T}$ - regrowth time.

Figure 3 - Average of leaf:stem ratio (a), leaf mass ratio (b) and root mass ratio (c) of Mombasa grass subjected to $\mathrm{N}$ supply $\left(0,25\right.$ and $50 \mathrm{mg} \mathrm{dm}^{-3}$ per week) during regrowth. 
$\mathrm{N}$ supply, plants invest most of their growth to roots instead of shoots. It is likely that response is an ecological adjustment to make the plants explore the soil environment for $\mathrm{N}$ uptake. Even with abundant solar radiation, plants under $\mathrm{N}$ restriction have problems to meet the requirements to produce more photosynthesizing pigments, impairing the assimilation process and the expansion of new leaf area for light interception.

The $\mathrm{N}$ supply ( 25 and $50 \mathrm{mg} \mathrm{dm}^{-3}$ of $\mathrm{N}$ ) increased the leaf:stem ratio up to 32 days of regrowth. The difference between these two treatments was low, considering the relative partitioning between aerial components (Figure 3), but enough to support up to $47.7 \%$ more total leaf biomass for higher $\mathrm{N}$ fertilization after 16 days of regrowth. Considering the best allocation of leaf biomass, the use of more $\mathrm{N}$ resulted in more efficient harvesting between 24 and 28 days. Within that range, the highest leaf mass ratio (Figure 3) and the lowest root mass ratio (Figure 3) were found. After that time and with $\mathrm{N}$ fertilization (particularly to $50 \mathrm{mg} \mathrm{dm}^{-3}$ of $\mathrm{N}$ ), the plants change the partitioning to other organs like roots and stem base, aiming at the restoration of reserves.

Some authors have found higher $\mathrm{N}$ use efficiency to moderate than to high fertilizations (Rodrigues et al., 2008). A common argument to these findings is related to the dilution of $\mathrm{N}$ between more structural components particularly from cell wall. Although the $\mathrm{N}$ use efficiency is significant for the management of fertilizations, it should not be overlooked that in different pasture production systems, the higher animal production efficiency is influenced by other factors, with the amount of forage allowance as one of the main targets to be reached.

\section{Conclusions}

Tiller population is the main structural aspect to support aboveground biomass recovery of Mombasa grass up to 32 days of regrowth. In fact, nitrogen changes the biomass partitioning during regrowth, supporting improved root and leaf biomass recovery. Higher $\mathrm{N}$ supply reduces the mobilization of stem base and root masses to sustain shoot production in approximately 10-13 days after defoliation, respectively. Mombasa grass is a species very responsive to nitrogen use with better performance to increased rates of fertilization after 6-11 days of regrowth. Under high $\mathrm{N}$ supply, Mombasa grass can be harvest around 24-28 days of regrowth. These days saved during the regrowth may represent an average increase in harvest efficiency of $18 \%$.

\section{References}

ALENCAR, C.A.B.; OLIVEIRA, R.A.; CÓSER, A.C. et al. Produção de seis capins manejados por pastejo sob efeito de diferentes doses nitrogenadas e estações anuais. Revista Brasileira de Saúde e Produção Animal, v.11, n.1, p.48-58, 2010.

ALEXANDRINO, E.; NASCIMENTO JÚNIOR, D.; MOSQUIM, P.R. et al. Características morfogênicas e estruturais na rebrotação da Brachiaria brizantha cv. Marandu submetida a três doses de nitrogênio. Revista Brasileira de Zootecnia, v.33, n.6, p.1372-1379, 2004.

BATISTA, K.; MONTEIRO, F.A. Respostas morfológicas e produtivas do capim- marandu adubado com doses combinadas de nitrogênio e enxofre. Revista Brasileira de Zootecnia, v.35, n.4, p.1281-1288, 2006.

BELARMINO, M.C.J.; PINTO, J.C.; ROCHA, G.P. et al. Altura de perfilho e rendimento de matéria seca de Capim-Tanzânia em função de diferentes doses de superfosfato simples e sulfato de amônio. Ciência e Agrotecnologia, v.27, p.879-885, 2003.

BRAGA, G.J.; PINEDO, L.A.; HERLING, V.R. et al. Produção de matéria seca e fluxo de tecidos de Cynodon spp. cv. Tifton $85 \mathrm{em}$ resposta a doses de nitrogênio. Acta Scientiarum, v.22, p.851-857, 2000.

BRAGA, G.J.; LUZ, P.H.C.; HERLING, V.R. et al. Resposta do capim-mombaça a doses de nitrogênio e a intervalos de corte. Acta Scientiarum. Animal Sciences, v.26, n.1, p.123-128, 2004.

CAMINHA, F.O.; SILVA, S.C.; PAIVA, A.J. et al. Estabilidade da população de perfilhos de capim-Marandu sob lotação contínua e adubação nitrogenada. Pesquisa Agropecuária Brasileira, v.45, n.2, p.213-220, 2010.

DONAGHY, D.J.; FULKERSON, W.J. Priority forallocation of water soluble carbohydrate reserves during regrowth of Lollim perene. Grass and Forage Science, v.53, p.211-218, 1998.

DURU, M.; DUCROCQ, H. Growth and senescence of the successive leaves on a Cocksfoot tiller. Effect of nitrogen and cutting regime. Annals of Botany, v.85, p.645-653, 2000.

ELYAS, A.C.W.; PINTO, J.C.; FURTINI NETO, A.E. et al. Nitrogênio e saturação por bases no desempenho do capim Pojuca (Paspalum atratum Swalen cv. Pojuca) cultivado em vasos. Ciência e Agrotecnologia, v.30, p.554-561, 2006.

GARCEZ NETO, A.F.; NASCIMENTO JÚNIOR, D.; REGAZZI, A.J. et al. Respostas morfogênicas e estruturais de Panicum maximum cv. Mombaça sob diferentes níveis de adubação nitrogenada e alturas de corte. Revista Brasileira de Zootecnia, v.31, n.5, p.1890-1900, 2002.

GOMIDE, J.A. Produção de leite em regime de pasto. Revista Brasileira de Zootecnia, v.22, n.4, p.591-613, 1993.

HODGSON, J. Grazing management: Science into practice. New York: John Wiley \& Sons, 1990. 203p.

JANK, L. Melhoramento e seleção de variedade de Panicum maximum. In: SIMPÓSIO SOBRE MANEJO DA PASTAGEM, TEMA: O CAPIM COLONIÃO, 12., Piracicaba, 1995. Anais... Piracicaba: FEALQ, 1995. p.21-58.

LAVRES JUNIOR, J.; MONTEIRO, F.A. Perfilhamento, área foliar e sistema radicular do Capim-Mombaça submetido a combinações de doses de nitrogênio e potássio. Revista Brasileira de Zootecnia, v.32, n.5, p.1068-1075, 2003.

LEMAIRE, G.; CHAPMAN, D. Tissue flows in grazed plant communities. In: HODGSON, J.; ILliUS, A.W. (Eds.) The ecology and management of grazing systems. Wallingford: $C A B$ International, 1996. p.3-36.

MARSCHNER, H. Mineral nutrition of higher plants. London: Academic Press, 1995. 889p.

MARTHA JÚNIOR, G.B.; VILELA, L.; BARIONI, L.G. et al. Manejo da adubação nitrogenada em pastagens. In: SIMPÓSIO SOBRE MANEJO DA PASTAGEM, 21., 2004, Piracicaba. Anais... Piracicaba: Fundação de Estudos Agrários Luiz de Queiroz, 2004. p.155-216. 
MARTUSCELLO, J.A.; FONSECA, D.M.; NASCIMENTO JÚNIOR, D. et al. Características morfogênicas e estruturais do capimxaraés submetido à adubação nitrogenada e desfolhação. Revista Brasileira Zootecnia, v.34, n.5, p.1475-1482, 2005.

MELLO, S.Q.S.; FRANÇA, A.F.S.; LANNA, A.C. et al. Adubação nitrogenada em Capim-Mombaça: produção, enficiência de conversão e recuperação aparente do nitrogênio. Ciência Animal Brasileira, v.9, n.4, p.935-947, 2008.

MOREIRA, L.M.; MARTUSCELLO, J.A.; FONSECA, D.M. et al. Perfilhamento, acúmulo de forragem e composição bromatológica do capim-braquiária adubado com nitrogênio. Revista Brasileira de Zootecnia, v.38, n.9, p.1675-1684, 2009.

NABINGER, C.; MEDEIROS, R.B. Produção de sementes de Panicum maximum Jacq. In:SIMPÓSIO SOBRE O MANEJO DE PASTAGENS, 12., 1995, Piracicaba. Anais... Piracicaba: Fundação de Estudos Agrários Luiz de Queiroz, 1995. p.59-128.

RODRIGUES, R.C.; MOURÃO, G.B.; VALINOTE A.C. et al. Reservas orgânicas, relação parte aérea-raiz e c-n e eliminação do meristema apical no capim-xaraés sob doses de nitrogênio e potássio. Ciência Animal Brasileira, v.8, n.3, p.505-514, 2007.

RODRIGUES, R.C.; MOURÃO, G.B.; BRENNECKE, K. et al. Produção de massa seca, relação folha/colmo e alguns índices de crescimento do Brachiaria brizantha cv. Xaraés cultivado com a combinação de doses de nitrogênio e potássio. Revista Brasileira de Zootecnia, v.37, n3, p.394-400, 2008.

SANTOS, A.S.; SANTANA, C.V.S.; MISTURA, C. et al. Efeito da adubação nitrogenada e potássica na dinâmica, peso e número de perfilho do capim-aruana. Agropecuária Científica no SemiÁrido, v.3, p.18-22, 2007.

SANTOS, M.E.R.; FONSECA, D.M.; BALBINO, E.M. et al. Caracterização dos perfilhos em pastos de capim-braquiária diferidos e adubados com nitrogênio. Revista Brasileira de Zootecnia, v.38, n.4, p.643-649, 2009.

WHITEHEAD, D.C. Grassland nitrogen. Wallingford: CAB International, 1995. 397p. 